\title{
Does mixing of beech (Fagus sylvatica) and spruce (Picea abies) litter hasten decomposition?
}

\author{
Torsten W. Berger • Pétra Berger
}

Received: 25 September 2013 / Accepted: 3 December 2013 /Published online: 20 December 2013

(C) The Author(s) 2013. This article is published with open access at Springerlink.com

\begin{abstract}
Background and aims It is of practical relevance to know how much beech must be admixed to pure spruce stands in order to increase litter decomposition and associated nutrient cycling, since the formation of thick organic layers is commonly ascribed to the recalcitrance of spruce needles. We addressed the impact of tree species mixture within forest stands and within litter on mass loss and nutritional release from litter.

Methods Litter decomposition was measured in three adjacent stands of pure spruce (Picea abies), mixed beech-spruce and pure beech (Fagus sylvatica) on a nutrient-rich site and a nutrient-poor site over a 2-year period using litterbags which were filled with five different mixtures of beech and spruce litter.

Results Mass loss of beech litter was not higher than mass loss of spruce litter. Decay was primarily affected by tree species composition of the incubation stand and was faster in (mixed) beech forests stands than in spruce forests, while the influence of litter species and their mixtures on decay rates was small. Net transfers of nutrients between the two litter species (direct effects) in the mixed bags were minimal, since initial beech and spruce litter did not have different litter quality. However, in a few cases indirect effects (e.g., changing decomposer abundance and activity) caused non-
\end{abstract}

Responsible Editor: Alfonso Escudero.

T. W. Berger $(\triangle) \cdot$ P. Berger

Department of Forest- and Soil Sciences, Institute of Forest Ecology, University of Natural Resources and Live Sciences (BOKU), Peter Jordan-Straße 82, 1190 Vienna, Austria e-mail: torsten.berger@boku.ac.at additive patterns for the totals within the mixed bags, hastening decomposition within the first year.

Conclusions Greater accumulation of litter in spruce compared to beech stands is not a consequence of the inherent recalcitrance of needles. Adverse environmental conditions in spruce stands retard decomposition. Indirect effects on decomposition caused by stand mixture are not mimicked by litter mixtures within mesh bags.

Keywords Decomposition · Fagus sylvatica $\cdot$ Litter quality $\cdot$ Litterbag $\cdot$ Mixing effects $\cdot$ Picea abies

\section{Introduction}

Replacement of beech by spruce is associated with changes in soil acidity, soil structure and humus form, which are commonly ascribed to the recalcitrance (e.g., high $\mathrm{C} / \mathrm{N}$ ratios and lignin concentrations) of spruce (e.g., Ellenberg et al. 1986). The formation of thick organic layers in monocultures of spruce is associated with reduced tree growth and therefore "hampers forest productivity" (Kazda and Pichler 1998). Hence, knowing how much beech must be admixed to pure spruce stands in order to increase litter decomposition, is of practical relevance for forest management strategies, since conversion of secondary pure spruce stands to mixed species stands is a current issue in Europe (Spiecker et al. 2004).

Decomposition processes are important for cycling of nutrients in forest ecosystems and are influenced by macro- and micro-climate, litter quality, activity of 
decomposing organisms and soil nutrient status (Vesterdal 1999). Mixing litter from species with differing resource quality and leaf structure changes the chemical environment and physically alters the total litter surface where decomposition is occurring (Hector et al. 2000). These alterations can also affect decomposer abundance and activity (Scheu et al. 2003). Thus, chemical and physical changes in leaf mixtures can influence decomposition rates both directly (physically) and indirectly (through the decomposer community and its activities). Gartner and Cardon (2004) found 30 papers that focus directly on decomposition of mixtures of litters, assessing whether decay rates in species mixtures can be predicted from known decay rates of the component litters (additive effects) decaying alone, but, i.e., not a single paper in this review explored decomposition of mixed beech-spruce litter, simultaneously examining the decay of the component single species. The term "decomposition", used in this study, comprises both mass loss (decay rate) and nutrient release (including nutrient transfers among leaves of different species), which are not necessarily linked with each other. The review by Gartner and Cardon (2004) revealed that nutrient transfer among leaves of different species is striking, with $76 \%$ of the mixtures showing non-additive dynamics of nutrient concentrations. In accordance with the comprehensive work of Wardle et al. (1997) these non-additive effects of decomposing mixed litter are difficult to generalize. Whether nutrient transfers within the decomposing litters are mediated by physical (e.g., leaching) or biological (e.g., fungi) means, nutrients released from rapidly decaying, higher-quality litter can stimulate decay in adjacent, more recalcitrant litters (McTiernan et al. 1997; Sariyildiz et al. 2005) or conversely, leaf litter decay can be slowed by release of inhibitory compounds such as phenolics including tannins (Fyles and Fyles 1993; Prescott et al. 2000). There are also recent indications that decay rates of litter mixtures may display additive characteristics (Vivanco and Austin 2008; Hoorens et al. 2010; Jacob et al. 2010).

In accordance with Prescott et al. (2004) the longheld belief that slow decomposition of spruce needle litter is responsible for the formation of thick organic layers and reduced productivity in spruce stands relative to beech forests needs critical testing: "Although we do not actively manage litter decomposition, several assumptions about decomposition are implicit in our expectations. For example, we expect that adding or increasing the broadleaf component will improve the site by increasing nutrient cycling and availability, partly through its higher quality litter and faster decay". Hence, in a recent publication (Berger and Berger 2012), we focused on purported "safe" generalizations about beech litter and its decomposition in single and mixed (50:50\%) spruce-beech litter combinations. We measured litter decomposition in three adjacent stands of pure spruce (Picea abies), mixed beech-spruce and pure beech (Fagus sylvatica) on three nutrient-rich sites (bedrock: Flysch) and three nutrient-poor sites (bedrock: Molasse; yielding a total of 18 stands) over a 3-year period using the litterbag method and addressed the impact of tree species composition within forest stands and litter. Since this research is a complementary study to the previous one, citing short summaries of the answers to the questions asked by Berger and Berger (2012) bears repeating at this point: The expectation, that broadleaf components decay faster, was not fulfilled (question 1: Does beech litter decompose faster than spruce litter?). Decay (mass loss) and release of compounds building up the organic litter layer $\left(\mathrm{C}_{\mathrm{org}}, \mathrm{N}_{\text {tot }}, \mathrm{P}\right.$, $\mathrm{S}$ and lignin) and associated $\mathrm{K}$ were primarily affected by tree species composition of the incubation stand and were faster in (mixed) beech forest stands than in spruce forests (question 2: Does litter decompose faster in beech or mixed beech-spruce forests than in spruce forests?). Mass loss did not differ between single and mixed spruce litter or between single and mixed beech litter but mixing beech and spruce litter tended to increase decay of spruce needles after the first year (question 3: Does mixing of beech and spruce litter hasten decomposition of spruce litter?). Mass loss was driving the release of the main components of the organic substance $\left(\mathrm{C}_{\text {org }}\right.$, lignin, $\mathrm{N}_{\text {tot }}, \mathrm{P}$ and $\left.\mathrm{S}\right)$ and associated $\mathrm{K}$ but nutrient release of the base cations (except $\mathrm{K}$ ) and $\mathrm{Mn}$ and $\mathrm{Fe}$ was not related to mass loss (question 4: Does mass loss correlate with nutrient release?). The initial element content in the litter explained most of the variation in the release of the same element for $\mathrm{P}, \mathrm{Mg}, \mathrm{K}, \mathrm{Na}$ and lignin; the (non-chemical) soil environment (e.g., micro-climate, physical conditions, activity of decomposing organisms) primarily controlled the decomposition rate $k$ (mass loss) and $\mathrm{C}_{\text {org }}$ release and to a lesser extent release of $\mathrm{N}_{\text {tot }}$, $\mathrm{S}$ and lignin; soil nutrition parameters helped to explain part of the remaining variance in release of $\mathrm{S}, \mathrm{Mg}, \mathrm{K}$ and lignin (question 5: Which parameters represent the best suite of characteristics that actually control decay rates and nutrient release?). 
Within the overall approach (see above; Berger and Berger 2012) this study was designed to pick up Question 3 in more details: Does mixing of beech and spruce litter hasten decomposition? Again, we measured litter decomposition in three adjacent stands of pure spruce, mixed beech-spruce and pure beech but only at the most intensively studied experimental site of each substrate for soil formation: Kreisbach (nutrient-rich site on Flysch) and Frauschereck (nutrient-poor sites on Molasse; yielding a total of six stands) over a 2-year period. However, this time, litter bags were filled with five instead of three different mixtures of spruce and beech litter enabling supplementary methods to test the hypothesis that decomposition and nutrient release of foliage litter of beech and spruce indicates non-additive effects of litter mixtures. Since separate sets of litterbags were exposed over a deviating time period this study can be used to verify the conclusion of Berger and Berger (2012) that "greater accumulation of litter in spruce compared to beech stands (see Question 2 above) is not a consequence of the inherent recalcitrance of needles (see Question 1 above)".

\section{Materials and methods}

Study sites

Six sites were selected on the two different bedrocks Flysch and Molasse (3 comparable sites on each substrate). Beech and spruce were similarly mixed, before one stand at each site was converted into the current pure spruce stand. Mono specific beech stands (5-7 canopy dominant trees) were selected within the mixed species stands. Nutrient fluxes had been monitored for the same 18 stands and detailed site information is given by Berger et al. (2009a) for each of the 18 stands. The stand characteristics of the sites Kreisbach (Flysch) and Frauschereck (Molasse) are listed in Table 1, since this specific study on litter decomposition was performed only on these sites, which had been extensively studied before (Schmid and Kazda 2001, 2002; Berger et al. 2004b, 2006, 2009b, 2010). Standing timber volume and dominant tree heights are higher at Kreisbach, despite a somewhat younger stand age of beech. The stands are located on N- (Kreisbach) to W(Frauschereck) facing slopes. Precipitation declines from the western (Molasse) to the eastern (Flysch) parts of Austria.
Detailed site descriptions are given by Berger et al. (2009a). The substrate for soil formation at Kreisbach is Flysch. The Flysch zone is a narrow strip in the foothills of the Northern Limestone Alps from west to east throughout the country. Flysch consists mainly of old tertiary and mesozoic sandstones and clayey marls. Nutrient release from this bedrock is high and consequently the prevalent humus forms are mull (beech and mixed stands; less than $1 \mathrm{~cm}$ thickness) to intermediate types between mull and moder (pure spruce stand), indicating quick turnover of the forest floor (usually less than $2 \mathrm{~cm}$ thick). Soil parameters (Table 2) indicate nutrient-rich soils. Soils were classified as pseudogley (Scheffer and Schachtschabel 1998; FAO classification: stagnic cambisol), since horizons with a high fraction of fine material (loam to clay) cause temporary waterlogging (stagnation zone at approximately 40 $50 \mathrm{~cm}$ soil depth). There are hardly any shrubs and the total cover of the herb layer is between $5 \%$ (spruce) and $20 \%$ (beech). The natural forest vegetation of the mixed stands on Flysch is Asperulo odoratae-Fagetum (Mucina et al. 1993).

Parent material for soil formation at Frauschereck is Molasse, tertiary sediments (so-called "HausruckKobernausserwald" gravel), which consist mainly of quartz and other siliceous material (granite, gneiss, hornblende schist, pseudotachylite and colored sandstone). Because of this acidic bedrock with low rates of nutrient release, the dominant soil types are mainly semi-podzols (Scheffer and Schachtschabel 1998; intermediate soil type between cambisol and podzol; FAO classification: dystric cambisol). Humus form is acidic moder and the thickness of the forest floor layers varies between 8 and $10 \mathrm{~cm}$, indicating slow turnover and accumulation of nutrients. In general, soils on Molasse contain more organic carbon and are more acidic, more sandy and less supplied with nutrients than soils on Flysch (Table 2). There are no shrubs and the total cover of the herb layer is $10 \%$ (spruce) to $15 \%$ (beech). The natural forest vegetation of the mixed stands is Luzulo nemorosae-Fagetum (Mucina et al. 1993).

Soils

Mean soil parameters within the overall approach (18 stands) are given by Berger and Berger (2012) and the specific data for the sites Kreisbach and Frauschereck are listed in Table 2. Forest floor (O-horizon: $\mathrm{O}_{\mathrm{i}}+\mathrm{O}_{\mathrm{e}}+\mathrm{O}_{\mathrm{a}}$ ) and mineral soil $(0-10 \mathrm{~cm})$ were taken with a core 
Table 1 Forest stand characteristics of adjacent pure and mixed species stands at the experimental sites Kreisbach and Frauschereck according to a 1997 survey, modified from Berger et al. 2009a. Since mono specific beech stands (5-7 canopy dominant trees) were selected within the mixed species stands at Frauschereck, ha-related stand characteristics are the same for the mixed and the pure beech stand. At Kreisbach, the pure beech stand was large enough for a separate survey

\begin{tabular}{|c|c|c|c|c|c|c|c|c|c|c|c|}
\hline \multirow[t]{2}{*}{ Site } & \multirow{2}{*}{$\begin{array}{l}\text { Age } \\
\text { Years }\end{array}$} & \multirow{2}{*}{$\begin{array}{l}\text { Stems } \\
\mathrm{N} \mathrm{ha}^{-1}\end{array}$} & \multirow{2}{*}{$\begin{array}{l}\text { Timber } \\
\text { volume } \\
\mathrm{m}^{3} \mathrm{ha}^{-1}\end{array}$} & \multirow{2}{*}{$\begin{array}{l}\text { Basal } \\
\text { area } \\
\mathrm{m}^{2} \mathrm{ha}^{-1}\end{array}$} & \multirow{2}{*}{$\begin{array}{l}\text { Dominant } \\
\text { tree height } \\
\mathrm{m}\end{array}$} & \multirow{2}{*}{$\begin{array}{l}\text { Elevation } \\
\text { m a.s.1. }\end{array}$} & \multirow{2}{*}{$\begin{array}{l}\text { Slope } \\
\text { Degrees }\end{array}$} & \multirow{2}{*}{$\begin{array}{l}\text { Aspect } \\
\text { (from } \mathrm{N} \text { to } \mathrm{E} \text { ) } \\
\text { Degrees }\end{array}$} & \multirow{2}{*}{$\begin{array}{l}\text { Precipitation } \\
(1971-2000) \\
\mathrm{mm}\end{array}$} & \multicolumn{2}{|c|}{ Coordinates (WGS84) } \\
\hline & & & & & & & & & & $\mathrm{N}$ & $\mathrm{E}$ \\
\hline \multicolumn{12}{|l|}{ Kreisbach } \\
\hline Spruce & 53 & 1012 & 567 & 57 & 27.0 & 480 & 11 & 0.0 & 850 & $48^{\circ} 05^{\prime} 50^{\prime \prime}$ & $15^{\circ} 39^{\prime} 46^{\prime \prime}$ \\
\hline Mixed & 65 & 976 & 487 & 44 & 27.5 & 480 & 11 & 0.0 & 850 & $48^{\circ} 05^{\prime} 50^{\prime \prime}$ & $15^{\circ} 39^{\prime} 49^{\prime \prime}$ \\
\hline Beech & 65 & 960 & 588 & 47 & 28.0 & 480 & 11 & 0.0 & 850 & $48^{\circ} 05^{\prime} 50^{\prime \prime}$ & $15^{\circ} 39^{\prime} 54^{\prime \prime}$ \\
\hline \multicolumn{12}{|c|}{ Frauschereck } \\
\hline Spruce & 58 & 1264 & 432 & 51 & 22.0 & 710 & 8 & 292.5 & 1180 & $48^{\circ} 05^{\prime} 27^{\prime \prime}$ & $13^{\circ} 18^{\prime} 36^{\prime \prime}$ \\
\hline Mixed & 89 & 414 & 384 & 42 & 29.5 & 700 & 7 & 292.5 & 1180 & $48^{\circ} 05^{\prime} 33^{\prime \prime}$ & $13^{\circ} 18^{\prime} 39^{\prime \prime}$ \\
\hline Beech & 89 & 414 & 384 & 42 & 28.0 & 690 & 7 & 315.0 & 1180 & $48^{\circ} 05^{\prime} 35^{\prime \prime}$ & $13^{\circ} 18^{\prime} 36^{\prime \prime}$ \\
\hline
\end{tabular}

sampler of $70 \mathrm{~mm}$ diameter in summer 2006. There were three distributed replicate samples at each stand, which were pooled before analysis. Samples of forest floor and of mineral soil (fine soil, separated by sieving $<2 \mathrm{~mm}$ ) were analyzed for total content of $\mathrm{C}$ (LECO SC 444, USA), N (Kjeldahl method according to ÖNORM L1082; 2300 Kjeltec Analyzer Unit, Tecator, Sweden), P and S (both after digestion with $\mathrm{HNO}_{3} / \mathrm{HClO}_{4}$ according to ÖNORM L1085; ICPS, inductive coupled plasma spectrometry, Optima 3000 $\mathrm{XL}$, Perkin Elmer, USA). Organic carbon $\left(\mathrm{C}_{\mathrm{org}}\right)$ was calculated as total carbon minus $\mathrm{C}_{\mathrm{CaCO} 3}$ (Scheibler method: reaction of carbonates with $\mathrm{HCl}$ and volumetric determination of emerging $\mathrm{CO}_{2}$ according to ÖNORM L1084). Calcium, Mg, K, Na, Al, Fe and Mn were measured as total contents after digestion with $\mathrm{HNO}_{3}$ / $\mathrm{HClO}_{4}$ in the forest floor and as exchangeable cations $\left(0.1 \mathrm{M} \mathrm{BaCl}_{2}\right.$ extract) in the mineral soil by ICPS. Soil acidity was measured as $\mathrm{pH}$ with a glass $\mathrm{Ag} / \mathrm{AgCl}$ combination electrode with $\mathrm{KCl}$ reference electrode ( $10 \mathrm{~g}$ soil were mixed with $25 \mathrm{ml}$ of $0.01 \mathrm{M} \mathrm{CaCl}_{2}$ or deionized $\mathrm{H}_{2} \mathrm{O}$, stirred, and the $\mathrm{pH}$ was measured the next morning $30 \mathrm{~min}$ after stirring again). Elemental stocks were then calculated as the product of dry $\left(105^{\circ} \mathrm{C}\right)$ fine-soil masses (related to area and soil depth) and corresponding element contents. Microbial $\mathrm{C}\left(\mathrm{C}_{\mathrm{mic}}\right)$ was calculated as the difference in organic $\mathrm{C}$ between fumigated and non-fumigated (control) samples according to Schinner et al. (1996). Two replicates of each sample, $2.5 \mathrm{~g}$ fresh forest floor or $5 \mathrm{~g}$ fresh mineral soil, were fumigated for $24 \mathrm{~h}$ with ethanol-free chloroform at
$25{ }^{\circ} \mathrm{C}$. Subsequently the chloroform was removed by evacuation. Fumigated samples and controls were extracted with $25 \mathrm{ml} 0.5 \mathrm{M} \mathrm{K}_{2} \mathrm{SO}_{4}$ and filtered; extracts were kept frozen until analysis. Total dissolved organic carbon was analyzed in the extracts with a Shimadzu TOC-5050 Total Carbon Analyzer, Japan. Nonextracted amounts of microbial $\mathrm{C}$ were compensated for by a correction factor of $\mathrm{k}_{\mathrm{EC}}=0.35$.

\section{Litterbag experiment}

Litter of beech and spruce was collected by spreading nets from mid-September to late October 2005 under the pure stands of beech and spruce. Collected foliage litter was dried at $50{ }^{\circ} \mathrm{C}$ for $48 \mathrm{~h}$, however, all data in this paper are related to $105{ }^{\circ} \mathrm{C}$ dry weight, estimated from subsamples not used for the decomposition study.

Strips of polyethlylene nets (1-mm mesh) were folded to obtain double-layered litterbags $(10 \times 10 \mathrm{~cm}$ size), which were closed on the two open sides with high carbon steel paper-clips. The litterbags were filled with five different mixtures, yielding eight components to be analyzed: mixture 1: single spruce, component SP; mixture 2: spruce-beech ratios of 0.75:0.25, components $\mathrm{mSP}(0.25 \mathrm{BE})[=$ spruce needles of mixture 2] and $\mathrm{mBE}(0.75 \mathrm{SP})$ [= beech leaves of mixture 2]; mixture 3: spruce-beech ratios of $1: 1$, components $\mathrm{mSP}(0.50 \mathrm{BE})$ and $\mathrm{mBE}(0.50 \mathrm{SP})$; mixture 4 : spruce-beech ratios of 0.25:0.75, components $\mathrm{mSP}(0.75 \mathrm{BE})$ and $\mathrm{mBE}(0.25 \mathrm{SP})$; mixture 5: single beech, component 


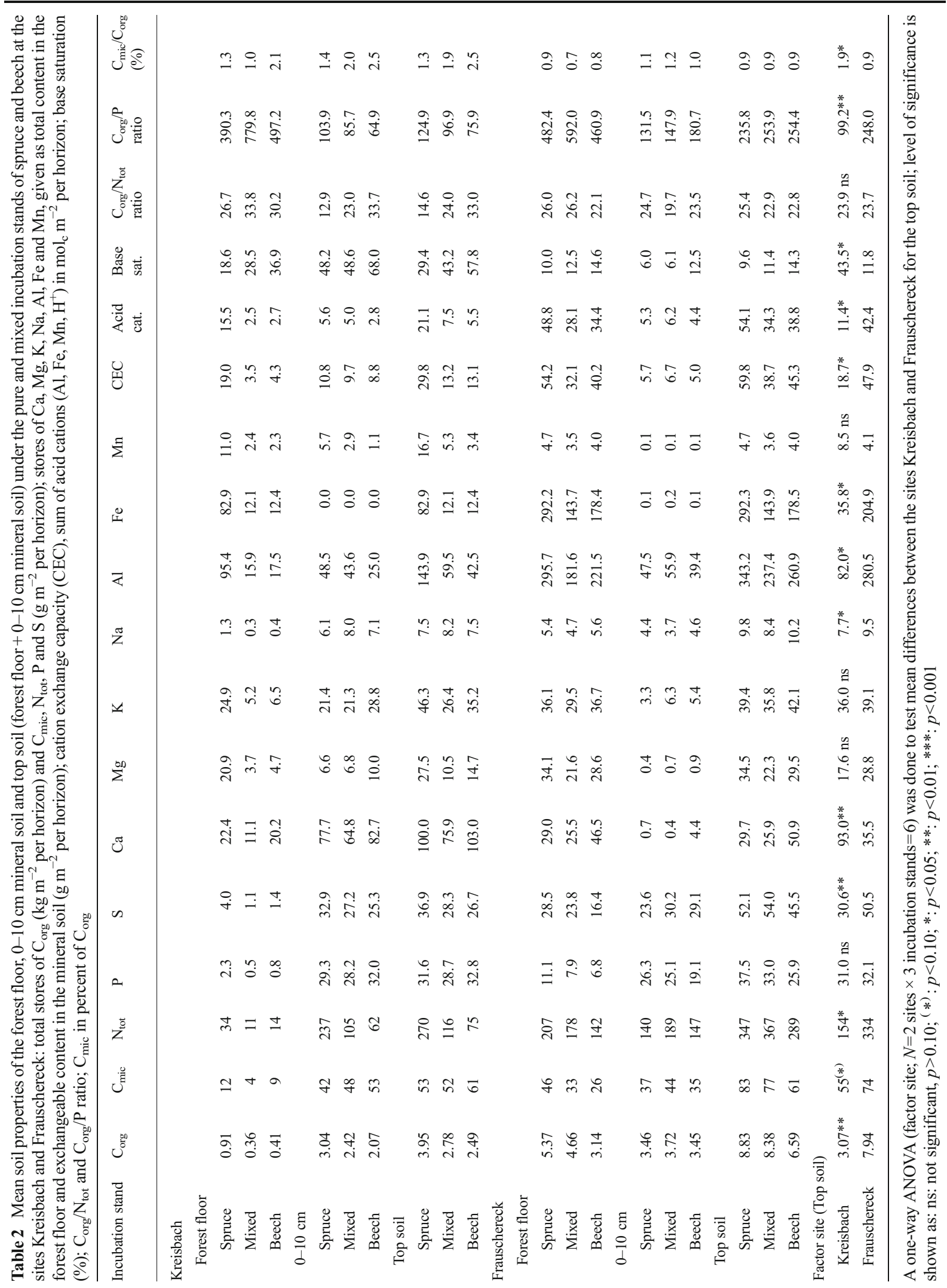


BE. The single spruce bags were filled with $2 \mathrm{~g}$, the single beech bags with $3 \mathrm{~g}$ and all mixed bags with a total of $4 \mathrm{~g}$ of dried $\left(50^{\circ} \mathrm{C}\right)$ litter. On an area basis these litter amounts $\left(195-390 \mathrm{~g} \mathrm{~m}^{-2}\right.$; related to $\left.105^{\circ} \mathrm{C}\right)$ represent the lower range of annual litter input (370$560 \mathrm{~g} \mathrm{~m}^{-2}$ year $^{-1}$ at Kreisbach; 310-370 $\mathrm{g} \mathrm{m}^{-2}$ year $^{-1}$ at Frauschereck; Berger et al. 2009b).

Beginning of December 2005 the litterbags were placed on the forest floor (after stripping off part of the non decayed leaves and needles of the $\mathrm{O}_{\mathrm{i}}$-layer and covering the bags thereafter again) in a randomized block design with four $0.4 \times 0.7 \mathrm{~m}$ blocks per stand. Each of the blocks contained two sets of the five litter mixtures for sampling at two different dates. The bags of each set were connected with each other by two strings along the left and right sites, tied to one wooden stick above and below each block. In addition, each individual bag was fastened to the forest floor by one $10 \mathrm{~cm}$ long pin of high carbon steel on the left and right side, outside the clipped seam. A total of 240 litterbags were used for the entire study $(2$ sites $\times 3$ incubation stands $\times$ 5 litter mixtures $\times 4$ replications per stand $\times 2$ sampling dates $=240$ ). Litter bags were collected twice after 1 and 2 years in November. Each set was returned horizontally in flat, piled-up boxes to avoid mass loss via transport. After drying at $40^{\circ} \mathrm{C}$ the bags were opened, non-foliage litter material was sorted out and the mixed bags were separated into its components by hand. Thereafter, the components of each individual bag were dried at $105^{\circ} \mathrm{C}$ for $48 \mathrm{~h}$, weighed and the 4 block replicates were subsequently pooled to give one sample and were ground for chemical analysis.

Contents of initial litter and after 1 and 2 years in the pooled litter samples were analyzed for $\mathrm{C}_{\text {org }}, \mathrm{N}_{\text {tot }}, \mathrm{P}, \mathrm{S}$, $\mathrm{Ca}, \mathrm{Mg}, \mathrm{K}, \mathrm{Na}, \mathrm{Al}, \mathrm{Fe}$ and $\mathrm{Mn}$ as described for the soil (forest floor) samples above. Total lignin content (acidinsoluble lignin plus acid-soluble lignin) was measured by Fourier transform near infrared (FT-NIR) spectrometry (Bruker FT-IR spectrometer, EQUINOX 55, Germany, equipped with NIR fibre optic (measuring the diffuse reflected light)) and a germanium-diode detector, limited by a cut-off wavenumber of $5100 \mathrm{~cm}^{-1}$ (details of the method are given in Schwanninger et al. 2009). This indirect method proved to be a powerful tool for rapid estimation of the lignin content in agreement with direct classical wet-lab chemistry data (Schwanninger and Hinterstoisser 2002). Microbial C $\left(\mathrm{C}_{\text {mic }}\right)$ was measured only in the initial samples as done for the fresh forest floor samples.
Data evaluation and statistics

Mass loss was calculated as the difference between the initial dry mass and the actual dry mass at each sampling date. Nutrient release was estimated as initial content minus content at each sampling date and expressed either in $\%$ of the initial content or in $\mathrm{mg} \mathrm{g}^{-1}$ incubated litter.

One-way ANOVAs were performed to test whether significant differences of soil properties (site) and initial litter chemistry (litter mixture, site) were caused by the corresponding grouping variables (given in parentheses). The largest data set was used for the performance of a three-way $(2 \times 3 \times 8)$ ANOVA to test effects of site (nutrient-rich soils at Kreisbach versus nutrient-poor soils at Frauschereck), incubation stand (spruce, mixed, beech) and litter mixture (single spruce, SP; mixed spruce with $25 \%[\mathrm{mSP}(0.25 \mathrm{BE})], 50 \%[\mathrm{mSP}(0.50 \mathrm{BE})]$ and $75 \%$ $[\mathrm{mSP}(0.75 \mathrm{BE})]$ admixture of beech; mixed beech with $25 \%[\mathrm{mBE}(0.25 \mathrm{SP})], 50 \%[\mathrm{mBE}(0.50 \mathrm{SP})]$ and $75 \%$ $[\mathrm{mBE}(0.75 \mathrm{SP})]$ admixture of spruce; single beech, $\mathrm{BE})$ on the remaining mass ( $\%$ of initial value) for each sampling date $(N=2$ sites $\times 3$ incubation stands $\times 8$ litter mixture components $\times 4$ replications per stand $=192$ ). In case of significant interactions between the grouping factors these factors can not be tested individually but affect the dependant factor jointly. Differences between the group means of each litter mixture component were compared by Duncan multiple range tests. Because the 4 replications per stand were pooled before chemical analysis the same three-way ANOVA could not be performed on the remaining element contents (\% of initial value), nutrient release $\left(\mathrm{mg} \mathrm{g}^{-1}\right)$ and selected compound ratios of litter enclosed in mesh bags due to a shortage of degrees of freedom. Hence, our best estimate was achieved by splitting up the three-way ANOVA into a two-way ANOVA (factors site and incubation stand) and a one-way ANOVA (factor litter mixture) and comparison of means by a Duncan multiple range test.

Predicted remaining masses and nutrient contents were calculated for each of the two mixed species within the mixed bags by linear interpolation from the single species mixtures of spruce and beech according to the initial ratio of mass and nutrient content, respectively. Significant differences (paired $t$-test) between predicted and measured total (mixed spruce + mixed beech within a bag) values in the mixed litter bags of all 3 combinations $(25,50$ and $75 \%$ admixture of beech) were calculated at the stand level (grouped by sampling date, site 
and incubation stand; $N=3$ mixed bags; indicated as positive or negative in complex figures) and on the site level $(N=3$ incubation stands $\times 3$ mixed bags $=9)$. For the latter case, differences between predicted and measured values for specific mixtures were compared by a Duncan multiple range test. According to this method, mass loss and nutrient release, respectively, can be predicted from the component litters decomposing alone (additive effects) for all cases the paired $t$-test does not indicate significant differences. All statistics were performed with the package PASW Statistics 17 (Release 17.0.2, 11 March 2009).

\section{Results}

Soils

Soil properties of the top soil (forest floor $+0-10 \mathrm{~cm}$ mineral soil) indicated significant differences between the soils at Kreisbach and Frauschereck for all listed parameters (Table 2) except stores of $\mathrm{P}, \mathrm{Mg}, \mathrm{K}$ and $\mathrm{Mn}$ and the $\mathrm{C}_{\text {org }} / \mathrm{N}_{\text {tot }}$ ratio. Since a slower turnover causes higher accumulation of the forest floor at Frauschereck, nutrient stores were significantly enriched for all elements except Mn (statistics are not shown in Table 2). The forest sites at Kreisbach had higher base saturation, higher $\mathrm{C}_{\text {mic }} / \mathrm{C}_{\text {org }}$ ratios but lower $\mathrm{C}_{\text {org }} / \mathrm{P}$ ratios within the top soil. Comparing individual base cation storages within the $0-10 \mathrm{~cm}$ mineral soil (significantly higher for $\mathrm{Ca}, \mathrm{Mg}, \mathrm{K}$ and $\mathrm{Na}$ at Kreisbach; not shown in Table 2), justifies calling soils at Kreisbach nutrientrich and soils at Frauschereck nutrient-poor.

As documented elsewhere (Berger et al. 2002, 2004a), acidifying effects of spruce were more pronounced on soils formed over Flysch than on Molasse. No statistics could be performed for the single sites, but there is a clear trend that even at both sites base saturation is increasing and the sum of aicid cations is decreasing from spruce to mixed to beech stands. Soil $\mathrm{pHs}\left(\mathrm{CaCl}_{2}\right)$ at $0-10 \mathrm{~cm}$ from spruce $(3.5 ; 3.3)$ to mixed $(3.7 ; 3.1)$ to beech $(4.0 ; 3.1)$ illustrate soil acidifying effects of spruce at Kreisbach (first value) but not at Frauschereck (second value within parentheses; not shown in Table 2).

Initial litter quality

Initial element contents and ratios of lignin $/ \mathrm{N}_{\text {tot }}, \mathrm{C}_{\mathrm{org}} /$ $\mathrm{N}_{\text {tot }}, \mathrm{C}_{\text {org }} / \mathrm{P}$ and $\mathrm{C}_{\text {mid }} / \mathrm{C}_{\text {org }}$ of spruce (SP) and beech (BE) litter, collected at adjacent spruce and beech stands at Kreisbach and Frauschereck in fall 2005, are given in Table 3. There is a clear trend that the base cation $(\mathrm{Ca}$, $\mathrm{Mg}$ and $\mathrm{K}$ ) and $\mathrm{C}_{\text {mic }}$ contents and the $\mathrm{C}_{\text {mic }} / \mathrm{C}_{\text {org }}$ ratio are higher in beech than in spruce. In all other cases differences between beech and spruce were negligible or indicated even lower quality of beech litter (i.e.: higher lignin and higher lignin/ $\mathrm{N}_{\text {tot }}$ ratios for beech than for spruce; Table 3). These data are in accordance with mean chemistry of initial litter, collected in fall 2004 within the overall approach at 3 sites on Flysch and Molasse, respectively, by Berger and Berger (2012). Surprisingly, the different nutritional status of soils at Kreisbach and at Frauschereck (Table 2) was not reflected in initial litter chemistry (factor site; Table 3).

Mass loss

During the first year of exposure the remaining mass of incubated litter was affected by incubation stand, followed by site and litter mixture (ranked in the order of decreasing $F$-values; Table 4 ). During the second year of the experiment the incubation stand turned out to be the main controlling factor of mass loss (100 - remaining mass in \%), though there was still a small effect of litter species and mixture. Surprisingly, soil chemistry (site) did not affect mass loss after a relatively short time period. However, significant interactions between site and incubation stand and between site and litter mixtures continued, indicating that these factors could not be tested individually. It is striking that these small but significant differences between the 8 individual litter mixture components (litter mixture) did not vary with stand composition (incubation stand), since there was no interaction between these two factors. Overall group means of each litter mixture component $(N=24$ per sampling date) and results of the attached post-hoc multiple comparisons (Duncan multiple range test) are plotted in Fig. 1. During the first year single beech decayed significantly slower than single spruce litter, however, in all cases the mixed litter decayed faster than the single litter within the same species. After 2 years, significant differences between the remaining mass of single spruce and single beech litter ceased and there was no clear trend visible any longer that mixing speeds up decay of the same species. The neat story about Fig. 1 is the fact that single and mixed spruce litter (needle litter) components occupy the 4 lower ranks (meaning faster decay) and the single and mixed beech litter (leaf 
Table 3 Initial nutrient contents $\left(\mathrm{mg} \mathrm{g}^{-1}\right)$, ratios of lignin $/ \mathrm{N}_{\text {tot }}, \mathrm{C}_{\text {org }} / \mathrm{N}_{\text {tot }}$ and $\mathrm{C}_{\text {org }} / \mathrm{P}$ and $\mathrm{C}_{\text {mic }}$ in percent of $\mathrm{C}_{\text {org }}$ of spruce (SP) and beech (BE) litter, collected at adjacent spruce and beech stands at the sites Kreisbach and Frauschereck in fall 2005

\begin{tabular}{|c|c|c|c|c|c|c|c|c|c|c|c|c|c|c|c|c|c|}
\hline Litter mixture & $\mathrm{C}_{\text {org }}$ & $\mathrm{C}_{\text {mic }}$ & Lignin & $\mathrm{N}_{\text {tot }}$ & $\mathrm{P}$ & S & $\mathrm{Ca}$ & $\mathrm{Mg}$ & K & $\mathrm{Na}$ & $\mathrm{Al}$ & $\mathrm{Fe}$ & $\mathrm{Mn}$ & $\begin{array}{l}\text { Lignin } / \mathrm{N}_{\text {tot }} \\
\text { ratio }\end{array}$ & $\begin{array}{l}\mathrm{C}_{\text {org }} / \mathrm{N}_{\text {tot }} \\
\text { ratio }\end{array}$ & $\begin{array}{l}\mathrm{C}_{\text {org }} / \mathrm{P} \\
\text { ratio }\end{array}$ & $\begin{array}{l}\mathrm{C}_{\text {mid }} / \mathrm{C}_{\text {org }} \\
(\%)\end{array}$ \\
\hline \multicolumn{18}{|l|}{ Kreisbach } \\
\hline SP & 494.8 & 0.7 & 273.6 & 8.5 & 0.5 & 0.8 & 12.2 & 0.7 & 3.4 & 0.1 & 0.2 & 0.2 & 2.5 & 32.3 & 58.4 & 923.2 & 0.2 \\
\hline $\mathrm{BE}$ & 495.0 & 8.2 & 392.8 & 9.7 & 0.6 & 1.2 & 14.7 & 1.7 & 6.1 & 0.1 & 0.4 & 0.3 & 1.1 & 40.3 & 50.8 & 838.6 & 1.7 \\
\hline \multicolumn{18}{|l|}{ Frauschereck } \\
\hline SP & 511.6 & 0.4 & 285.6 & 9.5 & 0.7 & 0.8 & 4.6 & 0.5 & 2.1 & 0.2 & 0.2 & 0.1 & 1.0 & 30.0 & 53.7 & 779.2 & 0.1 \\
\hline $\mathrm{BE}$ & 504.4 & 14.5 & 442.6 & 7.6 & 0.7 & 1.0 & 11.6 & 1.2 & 3.1 & 0.1 & 0.1 & 0.1 & 1.1 & 58.4 & 66.6 & 718.4 & 2.9 \\
\hline \multicolumn{18}{|c|}{ Factor litter mixture } \\
\hline SP (All) & 503.2 & $0.6^{(*)}$ & $279.6 *$ & 9.0 & 0.6 & $0.8^{(*)}$ & 8.4 & $0.6^{(*)}$ & 2.7 & 0.2 & 0.2 & 0.1 & 1.7 & 31.2 & 56.1 & 851.2 & $0.1^{(*)}$ \\
\hline BE (All) & 499.7 & 11.4 & 417.7 & 8.7 & 0.6 & 1.1 & 13.2 & 1.4 & 4.6 & 0.1 & 0.3 & 0.2 & 1.1 & 49.4 & 58.7 & 778.5 & 2.3 \\
\hline \multicolumn{18}{|l|}{ Factor site } \\
\hline $\begin{array}{l}\text { Kreisbach } \\
\text { (All) }\end{array}$ & $494.9^{(*)}$ & 4.5 & 333.2 & 9.1 & $0.6^{(*)}$ & 1.0 & 13.4 & 1.2 & 4.7 & 0.1 & 0.3 & 0.3 & 1.8 & 36.3 & 54.6 & 880.9 & 0.9 \\
\hline $\begin{array}{l}\text { Frauschereck } \\
\text { (All) }\end{array}$ & 508.0 & 7.4 & 364.1 & 8.5 & 0.7 & 0.9 & 8.1 & 0.9 & 2.6 & 0.2 & 0.1 & 0.1 & 1.0 & 44.2 & 60.2 & 748.8 & 1.5 \\
\hline
\end{tabular}

Two one-way ANOVAs were performed to test initial chemical differences between spruce and beech litter and between Kreisbach and Frauschereck $(N=2$ sites $\times 2$ litter mixtures $=4)$; only significant results are shown as: ${ }^{*}{ }^{*}: p<0.10 ; *: p<0.05 ;{ }^{* *}: p<0.01 ; * * *: p<0.001$

litter) components the 4 higher ranks (meaning slower decay) for each sampling date.

Finally, the average remaining mass after 2 years of decomposition amounted to $67 \%$ (spruce), $54 \%$

Table 4 ANOVA table of $F$-values on the effects of site (nutrientrich soils at Kreisbach versus nutrient-poor soils at Frauscherck), incubation stand (spruce, mixed, beech) and litter mixture on the remaining mass ( $\%$ of initial values) of litter enclosed in mesh bags. Litterbags were filled with five different mixtures, yielding eight components to be analyzed: single spruce, SP; spruce-beech ratios of $0.75: 0.25, \mathrm{mSP}(0.25 \mathrm{BE}), \mathrm{mBE}(0.75 \mathrm{SP})$; of $1: 1, \mathrm{mSP}(0.50 \mathrm{BE})$, $\mathrm{mBE}(0.50 \mathrm{SP})$; of $0.25: 0.75, \mathrm{mSP}(0.75 \mathrm{BE}), \mathrm{mBE}(0.25 \mathrm{SP})$; single beech, BE

\begin{tabular}{lrrrrr}
\hline Effects & df & $F$ & $p$ & \multicolumn{2}{c}{$p$} \\
\cline { 3 - 5 } & \multicolumn{3}{c}{ 1 year } & \multicolumn{2}{c}{2 year } \\
\hline Site (S) & 1 & 15.4 & 0.0001 & 0.1 & 0.7059 \\
Incubation stand & 2 & 33.0 & $<0.0001$ & 89.3 & $<0.0001$ \\
$\quad$ (I) & & & & & \\
Litter mixture (L) & 7 & 12.4 & 0.0000 & 3.1 & 0.0047 \\
S $\times$ I & 2 & 3.5 & 0.0343 & 8.4 & 0.0004 \\
S $\times$ L & 7 & 4.0 & 0.0005 & 2.2 & 0.0388 \\
\hline
\end{tabular}

A three-way $(2 \times 3 \times 8)$ ANOVA was performed for each sampling date after 1 and 2 years $(N=2$ sites $\times 3$ incubation stands $\times 8$ litter mixture components $\times 4$ replications per stand $=192$ ). Only significant interactions between the grouping factors are shown, indicating that these factors can not be tested individually but affect the dependent factor jointly (mixed) and $48 \%$ (spruce $>$ mixed $>$ beech), indicating the strong impact of the incubation stand (Table 5). Mean remaining mass was the same for both sites (56\%) due to the declining influence of soil type over time, as discussed above. Performing a one-way ANOVA (factor litter mixture), using the pooled stand means of 4 replications did not show any significant differences between the 8 litter mixture components any more.

\section{Nutrient release}

Hence, due to the reduced number of replications the same three-way ANOVA performed on remaining mass (Table 4, Fig. 1) had to be split up into a two-way ANOVA (factors site and incubation stand) and a oneway ANOVA (factor litter mixture and comparison of means by a Duncan multiple range test) to test factors controlling the remaining element contents ( $\%$ of initial value) and selected compound ratios of litter enclosed in mesh bags over a 2-year period (Table 5 ).

The factor site had little effect ( $F$-value: 9.36) on remaining carbon contents but no effect at all on remaining masses (see above), though both showed the same patterns and similar absolute values (Table 5). The soil type (factor site) further controlled the remaining contents of lignin, $\mathrm{N}_{\text {tot }}, \mathrm{Na}$ and Al. Stand composition (factor incubation stand) explained the variation in 


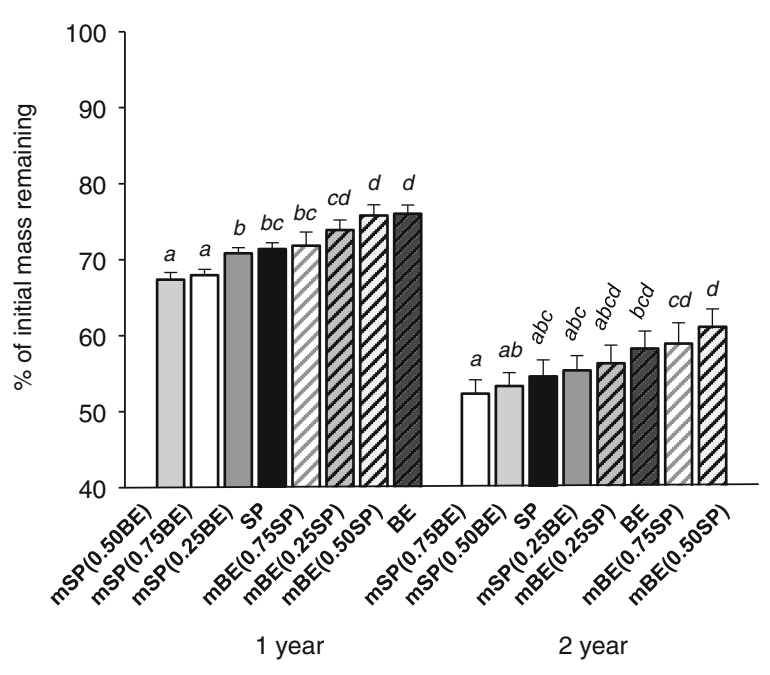

Fig. 1 Remaining mass (\% of initial values) of exposed litter mixtures in single and mixed species litter bags of spruce and beech. Litterbags were filled with five different mixtures, yielding eight components to be analyzed: single spruce, SP; spruce-beech ratios of $0.75: 0.25, \mathrm{mSP}(0.25 \mathrm{BE}), \mathrm{mBE}(0.75 \mathrm{SP})$; of $1: 1$, $\mathrm{mSP}(0.50 \mathrm{BE}), \mathrm{mBE}(0.50 \mathrm{SP})$; of $0.25: 0.75, \mathrm{mSP}(0.75 \mathrm{BE})$, $\mathrm{mBE}(0.25 \mathrm{SP})$; single beech, BE. A three-way $(2 \times 3 \times 8)$ ANOVA (factors site, incubation stand and litter mixture) was performed for each sampling date after 1 and 2 years (see Table 4). Plotted bars represent group means of each litter mixture component (standard errors were calculated for $N=2$ sites $\times 3$ incubation stands $\times 4$ replications per stand $=24$ ) and different letters indicate significant differences between them (Duncan multiple range test, $p<0.05$ )

nutrient release (100 - remaining nutrient content in \%) for all analyzed elements except $\mathrm{Ca}$ and $\mathrm{Mn}$. In cases where nutrient release was affected both by soil type and stand mixture, the latter explained most of the variation according to the $F$-values, except for $\mathrm{N}_{\text {tot }}$ and $\mathrm{Na}$ (Table 5).

Multiple range tests (one-way ANOVA; factor litter mixture) indicated different decreases of lignin (degradation) and nutrient releases for $\mathrm{N}_{\text {tot }}, \mathrm{Ca}$ and $\mathrm{Mn}$ (expressed in \% of initial values) between the 8 litter mixture components. Similar initial $\mathrm{C}_{\text {org }} / \mathrm{N}_{\text {tot }}$ and $\mathrm{C}_{\text {org }} / \mathrm{P}$ ratios (Table 3) for needle and leaf litter declined within 2 years of decomposition, resulting in lower end-values for leaf than for needle litter. However, not a single parameter, listed in Table 5, showed significant difference between single spruce - SP - and mixed spruce litter - $\mathrm{mSP}(0.25 \mathrm{BE}), \mathrm{mSP}(0.50 \mathrm{BE}), \mathrm{mSP}(0.75 \mathrm{BE})$ - or between single beech - BE - and mixed beech litter $\mathrm{mBE}(0.25 \mathrm{SP}), \mathrm{mBE}(0.50 \mathrm{SP}), \mathrm{mBE}(0.75 \mathrm{SP})$ - with the exception for the $\mathrm{C}_{\text {org }} / \mathrm{P}$ ratio in needle litter. Ranking the $\mathrm{C}_{\text {org }} / \mathrm{P}$ ratios within incubated mesh bags after 2 years from high to low corresponds to ranking the admixture of beech from 0 to $100 \%$, indicating nutrient transfer processes from one species to the other within mixed bags. For all other elements or element ratios, direct effects via nutrient transfer among litter of the different species seem unlikely, since these differences (grouping variable litter mixture) were only measured between leaves and needles in general.

So far, we expressed nutrient release (and remaining nutrient content, respectively) in \% of initial values, because this unit seems more appropriate for reporting relative changes caused by litter mixing. However, especially for elements with different initial litter contents between spruce and beech (see Table 3), absolute numbers on nutrient release in $\mathrm{mg} \mathrm{g}^{-1}$ incubated litter may yield different statistical results. Running a multiple range test attached to the one-way ANOVA of Table 5 with absolute instead of relative units yielded only one homogenous group for $\mathrm{Ca}(4.53-6.21)$ but two homogenous groups for $\mathrm{Mg}$ (needle litter, $a$ : $0.24-0.32$; leaf litter, $b: 0.69-0.81$ ) and $\mathrm{K}$ (needle litter, $a: 2.21-2.32$; leaf litter, $b: 3.73-3.84$; all data in element release in $\mathrm{mg} \mathrm{g}^{-1}$ incubated litter). For all other elements the number of homogenous groups (as result of a multiple range test) did not change. All data given in this paper as remaining nutrient content in $\%$ of initial value can be easily converted to nutrient release in $\mathrm{mg} \mathrm{g}^{-1}$ incubated litter by multiplying nutrient release in $\%$ (100 - remaining nutrient content in \%) with initial litter chemistry in $\mathrm{mg} \mathrm{g}^{-1}$ (given in Table 3).

As reported elsewhere (e.g., Prescott et al. 1993; Albers et al. 2004) nutrient immobilization during the early phases of decomposition may be followed by release of the same nutrient during later phases. Net remaining nutrient contents above $100 \%$ after 2 years of decomposition for $\mathrm{N}_{\text {tot }}$ and $\mathrm{Mn}$ (leaf litter), $\mathrm{S}$ (needle litter) and $\mathrm{Al}$ and $\mathrm{Fe}$ (both litter types) clearly indicate immobilization processes (Table 5), corresponding to negative absolute releases in $\mathrm{mg} \mathrm{g}^{-1}$ litter. The observed net immobilization of $\mathrm{Al}$ and $\mathrm{Fe}$ was in accordance with Schlesinger (1997), reporting that plant litter appears to absorb $\mathrm{Al}$ and $\mathrm{Fe}$, perhaps in compounds that are precursors to the fulvic acids.

\section{Prediction of mixed litter decomposition}

Direct effects via nutrient transfer of the studied elements among litter of the different species were excluded (compare Table 5). However, indirect effects (e.g., changing decomposer abundance and activity) were partly visible for total (mixed spruce + mixed beech 


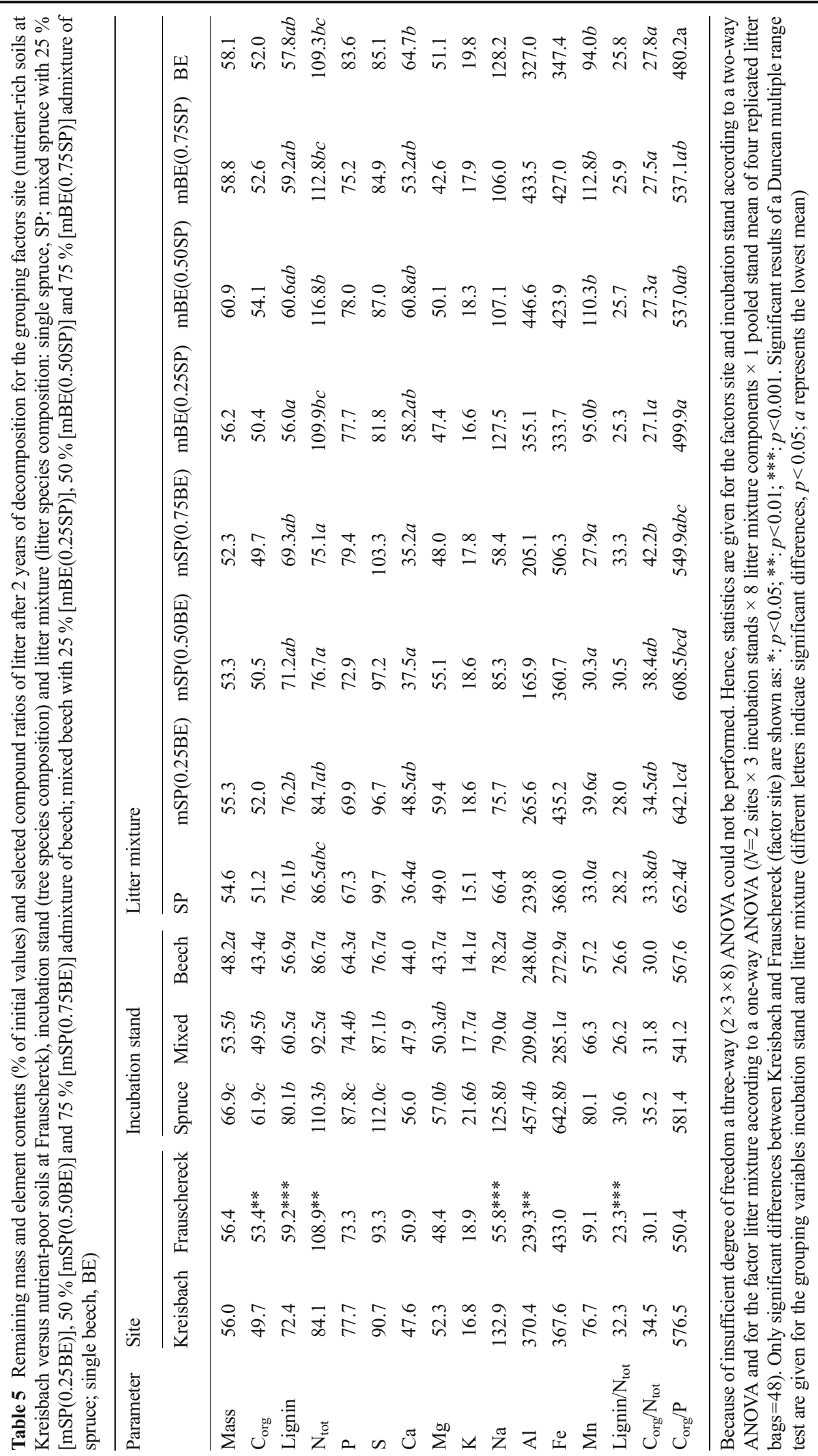


litter) remaining masses and element contents in the mixed litter bags, deviating from predicted values based upon single species mixtures of spruce and beech (this means, mass loss or nutrient release of both components within mixed bags may be driven jointly in either way). Out of 108 cases plotted in Figs. 2, 3 and 4 (grouped by remaining mass, $\mathrm{C}$, lignin and macro nutrients; year; site and incubation plot), litter mixtures displayed additive characteristics in 78 cases and non-additive characteristics in 30 cases. Out of the 30 (non-additive) cases, 21 cases were characterized by faster and 9 cases by slower decomposition rates than predicted. It is striking that out of these latter 9 cases only one case was recorded for $\mathrm{K}$ at Kreisbach (1 year, beech stand) while the majority of cases with retarded decomposition in the mixed bags occurred at the nutrient-poor soils at Frauschereck. We suggest that the decomposer diversity and abundance is not high enough (compare significantly lower $\mathrm{C}_{\text {mic }} / \mathrm{C}_{\text {org }}$ ratios in Table 2) to react immediately to freshly crosstransplanted litter.

Figures 2, 3 and 4 summarize the whole data set of the study, broken down on the lowest level cases: pooled stand means of 4 replicated sets of the five litter mixtures, which were connected with each other by two strings (see Materials and Methods section). Due to a shortage of replications for specific statistical tests, frequency analyses, e.g., via simple counting of hastened vs. slowed decomposition cases, helps to draw justified conclusions. Though each column is based upon just one chemical analysis it is easy to detect outliers visually, since the litter bag results are plotted on the $\mathrm{x}$-axis in the order of increasing admixture of beech $(\%$ of initial mass) for each case. Out of 864 plotted bars only 3 look like possible outliers or extreme values (questionmarked but kept in the graphs, since no mistakes were found). Predicted values of remaining masses and nutrient contents in \% of initial values are based upon linear interpolation from single species mixtures of spruce and beech and were plotted as line graph for each case. Note that litterbags were plotted in the order of increasing additions of leaf litter masses; consequently, deviations from a straight line are an indication that initial foliar chemistry was different between spruce and beech (compare Table 3).

We tried to summarize non-additive effects via grouping all 108 cases by site and year in Table 6, since we know that the effect of litter mixture on mass loss (non-pooled samples) did not vary with incubation stand (see above). Significant paired $t$-tests indicated without exception higher decomposition rates than predicted in the mixed litter bags at the nutrient-rich site Kreisbach, but slower rates than predicted for the nutrient-poor site Frauschereck. Performing the same tests on the whole data set for each year indicated that mass loss and release of $\mathrm{C}_{\text {org }}, \mathrm{N}_{\text {tot }}, \mathrm{P}, \mathrm{S}$ and $\mathrm{Ca}$ was hastened within the first year of decomposition but ceased thereafter. It is important to point out that non-additive effects of mixed litter were measured, though no differences between the single species were visible for most parameters.

Differences between predicted and measured values for specific mixtures $(25,50$ and $75 \%$ admixture of beech) were compared by a Duncan multiple range test to see which mixture had the biggest non-additive effect. With the exception of P (1 year, Frauschereck) none of the multiple comparisons yielded significant results. There was a trend that relatively low admixtures of beech (25\%) or spruce (corresponding to $75 \%$ admixture of beech) displayed the highest non-additional characteristics at Frauschereck (see column "ranked differences" in Table 6).

\section{Discussion}

Question 1: Does beech litter decompose faster than spruce litter?

i) Mass loss of single beech litter was not higher than mass loss of single spruce litter. During the first year decay of single beech litter was significantly lower than of single spruce, but differences declined over time.

ii) Net nutrient release in $\mathrm{mg} \mathrm{g}^{-1}$ incubated litter (after 2 years) of $\mathrm{N}_{\text {tot }}$, and $\mathrm{Mn}$ was higher in needle than in leaf litter due to high immobilization (retention) rates of beech.

iii) However, decrease of lignin and release of $\mathrm{Mg}$ and $\mathrm{K}\left(\mathrm{mg} \mathrm{g}^{-1}\right)$ were higher for leaf than needle litter.

Again, the common (implicit) expectation that the broadleaf components decay faster was not fulfilled in accordance with our overall approach (Berger and Berger 2012). Slower decay of beech versus spruce litter is in accordance with Vesterdal (1999; at one of 3 sites only), Albers et al. (2004) and Sariyildiz et al. (2005; comparison between Fagus orientalis and Picea orientalis). This finding agrees with Prescott et al. 


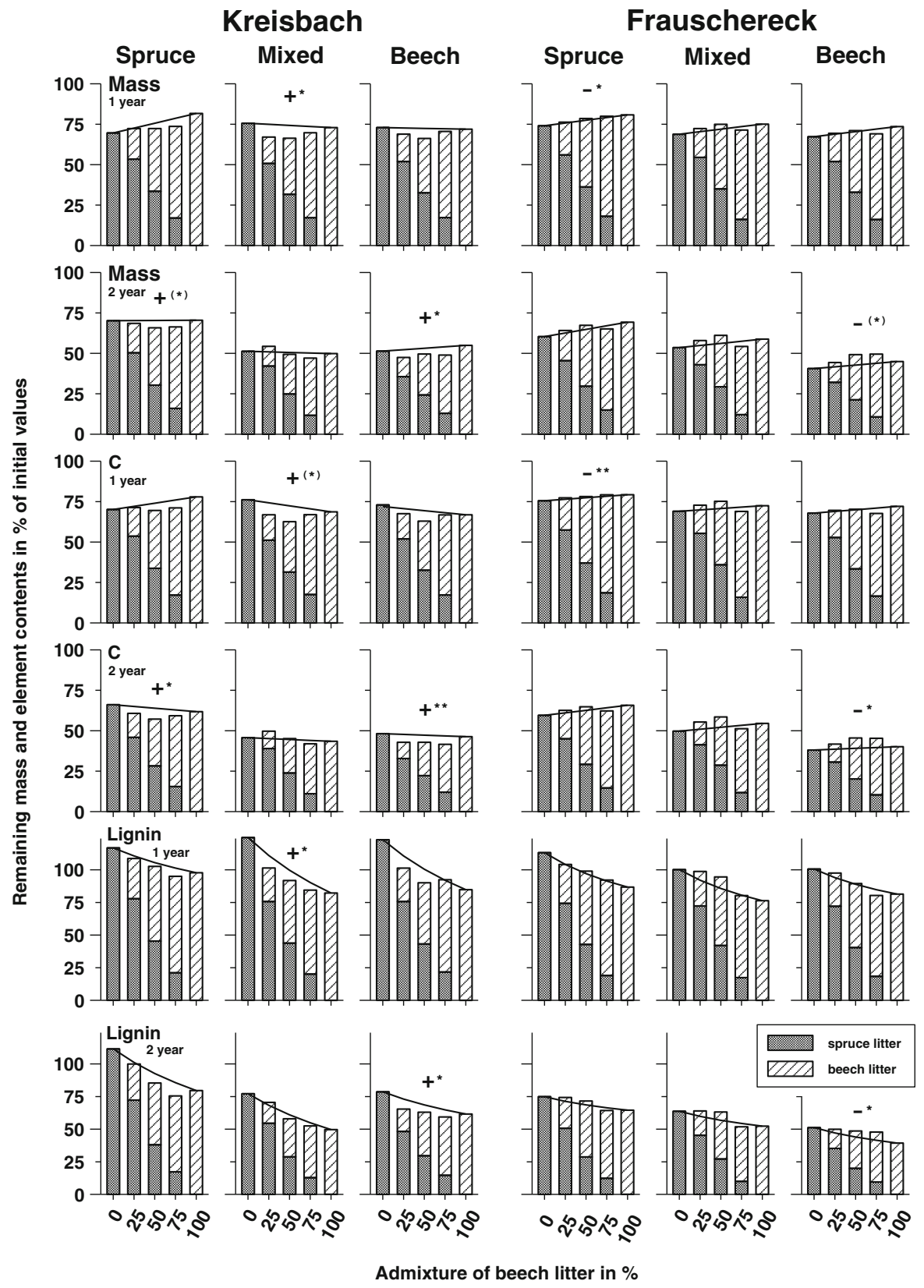

Fig. 2 Remaining mass and contents of $\mathrm{C}_{\mathrm{org}}$ and lignin (\% of initial values) of exposed litter mixtures in single and mixed species litter bags of spruce and beech after 1 and 2 years, grouped by site (Kreisbach, Frauscherck) and incubation stand (spruce, mixed, beech). Litterbags were filled with five different mixtures, plotted on the $\mathrm{x}$-axis in the order of increasing admixture (\% of initial mass) of beech. Each column represents just one pooled stand mean of four replicated litter bags. Predicted values, based

(2004) and Prescott (2010), stating that many broadleaf species do not decay faster than needles, and if they do this difference is only evident for the first $1-3$ years, upon linear interpolation from single species mixtures of spruce and beech, are potted as lines. Significant differences (paired $t$-test; $N=3$ ) between predicted and measured total (mixed spruce + mixed beech within a bag) remaining masses and element contents in mixed litter bags of all three combinations (25, 50 and $75 \%$ admixture of beech) are indicated + (if positive) or - (if negative); level of significance is shown as: ${ }^{*}: p<0.10$; *: $p<0.05$; **: $p<0.01 ; * * *: p<0.001$

after which time a similar or even greater proportion of the original mass of broadleaf litter may remain compared with needle litter. In accordance with Dungait 


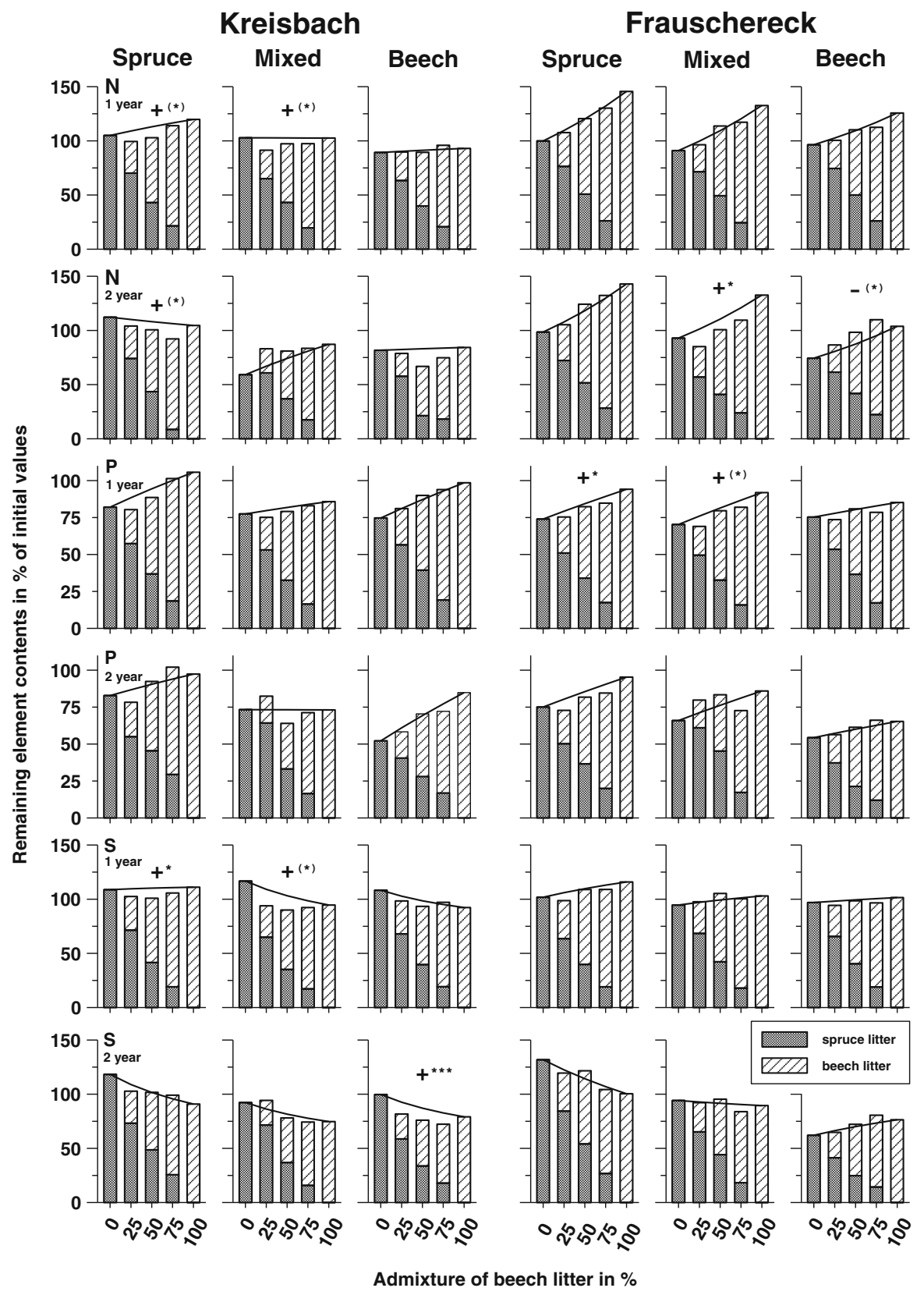

Fig. 3 Remaining contents of $\mathrm{N}_{\text {tot }}, \mathrm{P}$ and $\mathrm{S}$ (\% of initial values) of exposed litter mixtures in single and mixed species litter bags of spruce and beech after 1 and 2 years, grouped by site (Kreisbach, Frauscherck) and incubation stand (spruce, mixed, beech). Litterbags were filled with five different mixtures, plotted on the x-axis in the order of increasing admixture (\% of initial mass) of beech. Each column represents just one pooled stand mean of four replicated litter bags. Predicted values, based upon linear interpolation

et al. (2012) lignin is not as recalcitrant as thought. It has to be pointed out that the structure of lignin varies between tree species (a good overview of initial from single species mixtures of spruce and beech, are potted as lines. Significant differences (paired $t$-test; $N=3$ ) between predicted and measured total (mixed spruce + mixed beech within a bag) remaining element contents in mixed litter bags of all three combinations $(25,50$ and $75 \%$ admixture of beech) are indicated + (if positive) or - (if negative); level of significance is shown as: ${ }^{*}$ ): $p<0.10 ; *: p<0.05 ; * *: p<0.01$; ***: $p<0.001$

chemical patterns and their changes during lignin degradation is given for beech leaves and spruce needles by Klotzbücher et al. 2011). Obviously, the purported faster 


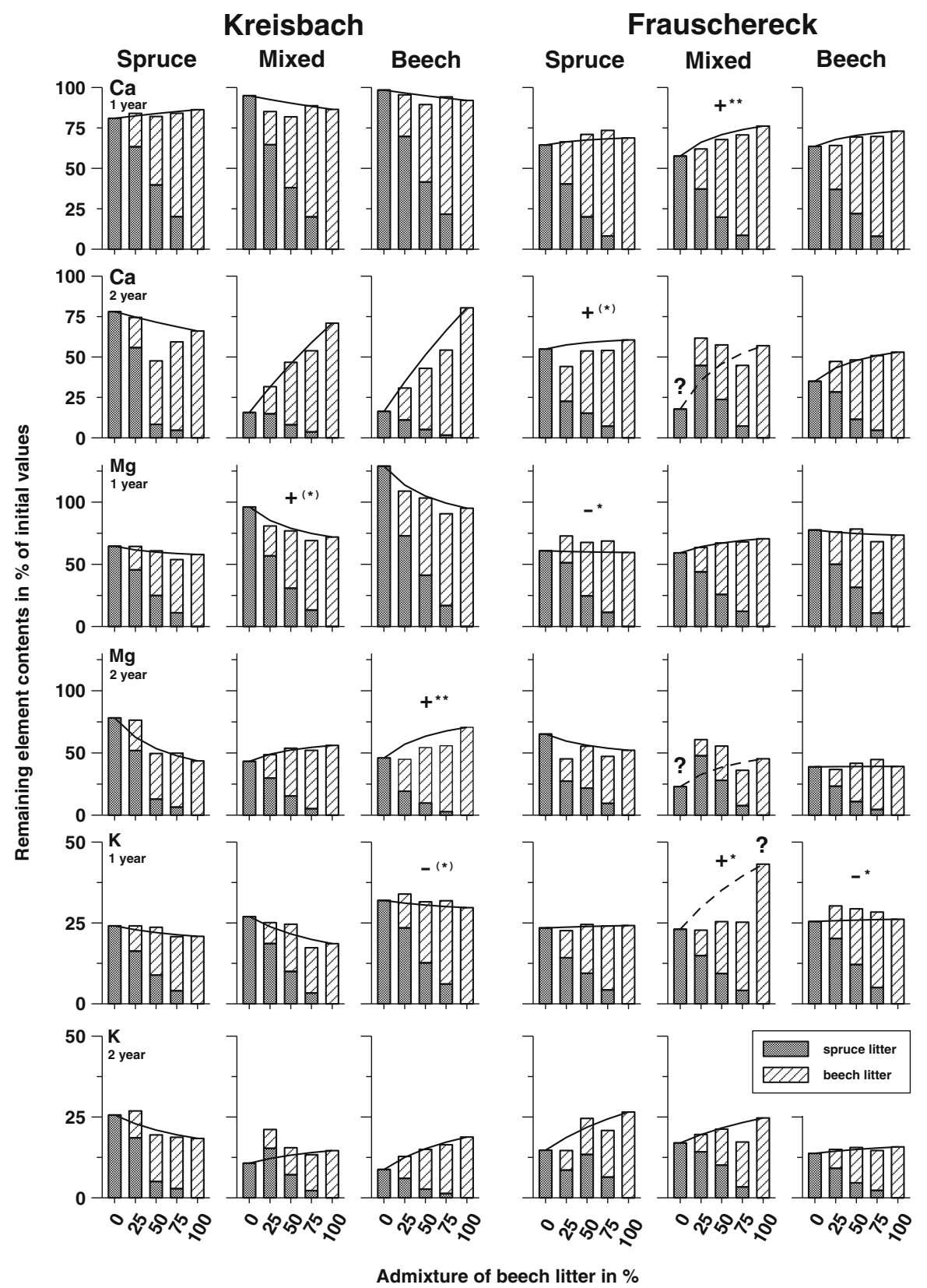

Fig. 4 Remaining contents of $\mathrm{Ca}, \mathrm{Mg}$ and $\mathrm{K}$ (\% of initial values) of exposed litter mixtures in single and mixed species litter bags of spruce and beech after 1 and 2 years, grouped by site (Kreisbach, Frauscherck) and incubation stand (spruce, mixed, beech). Litterbags were filled with five different mixtures, plotted on the $\mathrm{x}$-axis in the order of increasing admixture ( $\%$ of initial mass) of beech. Each column represents just one pooled stand mean of four replicated litter bags. Predicted values, based upon linear interpolation from single species mixtures of spruce and beech, are potted as

decomposition of beech leaf litter, as often reported in German textbooks (e.g., Ellenberg et al. 1986; Rehfuess lines. Significant differences (paired $t$-test; $N=3$ ) between predicted and measured total (mixed spruce + mixed beech within a bag) remaining element contents in mixed litter bags of all three combinations $(25,50$ and $75 \%$ admixture of beech) are indicated + (if positive) or - (if negative); level of significance is shown as: ${ }^{*}$ ): $p<0.10$; : $p<0.05$; **: $p<0.01$; **: $p<0.001$. Question marks indicate that the corresponding single species contents look like outliers, though no mistakes were found. Hence, calculated predicted values (dotted lines) must be interpreted with caution

1990), is not a safe generalization to make and, maybe, was deduced from the fact that fresh foliage of beech is 
Table 6 Significant mean differences (paired $t$-test) between predicted (linear interpolation from single species mixtures of spruce, $\mathrm{SP}$, and beech, BE) and measured total (mixed spruce + mixed beech within a bag) remaining masses and element contents ( $\%$ of

\begin{tabular}{|c|c|c|c|c|c|}
\hline \multirow{2}{*}{$\begin{array}{l}\text { Site } \\
\text { Year }\end{array}$} & \multirow[t]{2}{*}{ Parameter } & \multirow{2}{*}{$\begin{array}{l}\text { Predicted - measured } \\
\text { All mixed bags }\end{array}$} & $\mathrm{SP}$ & \multirow[t]{2}{*}{$\mathrm{BE}$} & \multirow{2}{*}{$\begin{array}{l}\text { Ranked differences } \\
\text { Specific mixtures }\end{array}$} \\
\hline & & & Single species bags & & \\
\hline \multicolumn{6}{|l|}{ Kreisbach } \\
\hline \multirow[t]{7}{*}{1 year } & Mass & $4.4^{* *}$ & 72.7 & $75.6 \mathrm{~ns}$ & $75,25,50 \mathrm{~ns}$ \\
\hline & $\mathrm{C}_{\text {org }}$ & $4.7^{*}$ & 72.8 & $71.2 \mathrm{~ns}$ & $75,25,50 \mathrm{~ns}$ \\
\hline & Lignin & $6.0 * *$ & 121.5 & $88.2 * *$ & $75,25,50 \mathrm{~ns}$ \\
\hline & $\mathrm{N}_{\text {tot }}$ & $4.8^{* *}$ & 99.1 & $105.2 \mathrm{~ns}$ & $75,50,25 \mathrm{~ns}$ \\
\hline & $\mathrm{S}$ & $7.1 * *$ & 111.2 & $99.3 \mathrm{~ns}$ & $75,25,50 \mathrm{~ns}$ \\
\hline & $\mathrm{Ca}$ & $2.5^{(*)}$ & 91.5 & $88.3 \mathrm{~ns}$ & $75,25,50 \mathrm{~ns}$ \\
\hline & $\mathrm{Mg}$ & $3.1^{*}$ & 96.5 & $75.0 \mathrm{~ns}$ & $50,25,75 \mathrm{~ns}$ \\
\hline \multirow[t]{4}{*}{2 year } & Mass & $2.7^{*}$ & 57.6 & $58.5 \mathrm{~ns}$ & $25,50,75 \mathrm{~ns}$ \\
\hline & $\mathrm{C}_{\text {org }}$ & $2.9^{*}$ & 53.3 & $50.5 \mathrm{~ns}$ & $25,50,75 \mathrm{~ns}$ \\
\hline & Lignin & $4.5^{* *}$ & 89.1 & $63.6 \mathrm{~ns}$ & $25,50,75 \mathrm{~ns}$ \\
\hline & $\mathrm{Ca}$ & $6.9^{*}$ & 36.8 & $72.5 \mathrm{~ns}$ & $25,75,50 \mathrm{~ns}$ \\
\hline \multicolumn{6}{|c|}{ Frauschereck } \\
\hline 1 year & $\mathrm{P}$ & $3.6^{* *}$ & 73.2 & $90.5 * *$ & $50<75,25^{*}$ \\
\hline \multirow[t]{3}{*}{2 year } & Mass & $-2.4^{(*)}$ & 51.5 & $57.7 \mathrm{~ns}$ & $50,25,75 \mathrm{~ns}$ \\
\hline & $\mathrm{C}_{\text {org }}$ & $-2.9 *$ & 49.1 & $53.4 \mathrm{~ns}$ & $50,25,75 \mathrm{~ns}$ \\
\hline & Lignin & $-2.8^{*}$ & 63.2 & $52.0 \mathrm{~ns}$ & $50,25,75 \mathrm{~ns}$ \\
\hline \multicolumn{6}{|l|}{ All } \\
\hline \multirow[t]{6}{*}{1 year } & Mass & $2.0^{*}$ & 71.4 & $76.0^{(*)}$ & $25,50,75 \mathrm{~ns}$ \\
\hline & $\mathrm{C}_{\text {org }}$ & $2.0^{*}$ & 71.8 & $72.9 \mathrm{~ns}$ & $25,75,50 \mathrm{~ns}$ \\
\hline & $\mathrm{N}_{\text {tot }}$ & $3.0 * *$ & 97.5 & $119.9 *$ & $50,75,25 \mathrm{~ns}$ \\
\hline & $\mathrm{P}$ & $2.7 * *$ & 75.7 & $93.6^{* *}$ & $50,75,25 \mathrm{~ns}$ \\
\hline & $\mathrm{S}$ & $4.4^{* *}$ & 104.5 & $103.0 \mathrm{~ns}$ & $75,50,25 \mathrm{~ns}$ \\
\hline & $\mathrm{Ca}$ & $1.7^{(*)}$ & 76.7 & $80.5 \mathrm{~ns}$ & $75,25,50 \mathrm{~ns}$ \\
\hline
\end{tabular}

Differences between predicted and measured values for specific mixtures were compared by a Duncan multiple range test $(p<0.05)$ and ranked in increasing order, if not significant $(N$ per site and year $=3$ incubation stands $\times 3$ mixed bags $\times 1$ pooled stand mean of four replicated litter bags $=9)$. The corresponding single species data are given for spruce $(\mathrm{SP})$ and beech $(\mathrm{BE})$ and means are compared via a oneway ANOVA $(N$ per site and year $=3$ incubation stands $\times 2$ single species bags $\times 1$ pooled stand mean of four replicated litter bags $=6$ )

of better quality than of spruce. E.g., comparisons between beech and spruce foliage at the 6 mixed beechspruce stands within the overall project by Berger et al. (2009a) indicated significantly higher nutrient concentrations of beech foliage for all elements (except for $\mathrm{Mn}$, and $\mathrm{P}$ at nutrient-rich sites only). Retranslocation of nutrients prior to senescence (Kristensen et al. 2004; Berger et al. 2009b; Carnol and Bazgir 2013) is greater in beech than in spruce foliage, which may have caused the negligible differences between initial spruce and beech litter in this study. We did not expect fresh spruce and beech litter to be of similar quality; under this initial values) in mixed litter bags of all 3 combinations (25, 50 and $75 \%$ admixture of beech), corresponding single species data for $\mathrm{SP}$ and $\mathrm{BE}$ and ranked differences of specific mixtures 
spruce forests. Litter decay indicated non-additive patterns at the nutrient-rich site Kreisbach, since similar remaining masses under pure beech $(50 \%)$ and mixed beech-spruce $(50 \%)$ were significantly lower than under pure spruce stands $(68 \%$; beech $=$ mixed $<$ spruce), however, linear (additive) reactions as expected from the pure stands at the nutrient-poor site Frauschereck: beech $(46 \%)<\operatorname{mixed}(57 \%)<$ spruce (66\%).

ii) Remaining element contents in \% of initial values after 2 years increased for all elements (except $\mathrm{Ca}$ ) significantly from beech over mixed to spruce stands and showed non-additive patterns at Kreisbach (beech $=$ mixed $<$ spruce) but additive patterns (beech $<$ mixed $<$ spruce) at Frauschereck for $\mathrm{C}_{\text {org }}$, lignin, $\mathrm{S}, \mathrm{K}$ and $\mathrm{Fe}$.

Although beech litter itself did not decay faster than spruce litter within 2 years, favorable environmental conditions in (mixed) beech stands increased litter decay. This is in accordance with the overall approach. However, very similar remaining masses were recorded within 3 years (beech: $47 \%$; mixed: $48 \%$; spruce: $67 \%$; means of 6 sites; Berger and Berger 2012) as within the 2 monitoring years of this study (beech: $48 \%$; mixed: $54 \%$; spruce: $67 \%$; means of 2 sites). Obviously, decay rates can vary strongly depending on climatic conditions. It is of practical relevance to know that the formation of thick organic layers in spruce monocultures, suggested to hamper productivity, can be avoided by admixture of beech and does not necessarily require complete stand conversion at nutrient-rich sites.

Question 3: Does mixing of beech and spruce litter hasten decomposition?

i) In general, the impact by litter species and their mixtures on decay rates was very small and was mainly driven by stand mixture.

ii) During the first year mixed litter decayed faster than the single litter within the same species, however, this visible trend that mixing speeds up decay ceased after 2 years.

iii) Direct effects via nutrient transfer among litter of the different species seemed unlikely, since all elements displayed the same release between single spruce and mixed spruce litter and between single beech and mixed beech litter, respectively. Nevertheless, in some cases indirect effects (e.g., changing decomposer abundance and activity) may explain the fact that non-additive pattern were visible for the totals (mixed spruce + mixed beech litter) within the mixed bags, driving decomposition of both components jointly in either way. E.g., mass loss and release of $\mathrm{C}_{\text {org }}, \mathrm{N}_{\text {tot }}, \mathrm{P}, \mathrm{S}$ and $\mathrm{Ca}$ was hastened within the first year of decomposition but ceased thereafter. At the nutrient-poor site Frauschereck retarded decomposition in the mixed litter bags was recorded in a few cases as well.

It is hypothesized that enhanced decay rate and nutrient release in mixtures of litter, as shown by a number of authors (Gartner and Cardon 2004 and references therein), is caused by translocation of nutrients between litters of different quality (direct effects), resulting in a more rapid and efficient utilization of litter substrate by decomposers. However, in accordance with Berger and Berger (2012), net transfers of nutrients between the two litter species in the mixed bags were minimal, since initial beech and spruce litter did not reveal different litter quality. Clear indirect effects on decomposition caused by stand mixture can not be mimicked by litter mixtures within mesh bags.

\section{Conclusions}

This study verified the conclusion of Berger and Berger (2012) that "greater accumulation of litter in spruce compared to beech stands is not a consequence of the inherent recalcitrance of needles". Faster decomposition of beech litter is not a safe generalization to make, and is obviously not the cause of the differences in soils beneath the two species. In accordance with Albers et al. (2004) we conclude that adverse environmental conditions in spruce stands retard decomposition. Mixed beech-spruce stands appear to be effective in counteracting these adverse conditions, preventing the accumulation of thick organic layers observed in spruce monocultures.

Acknowledgments This research was supported by the Austrian Science Fund (FWF, project numbers P 18208-B06 and P 23861B16; both granted to TW Berger). We thank Anita Gruber, Gerlinde Mistlberger, Monika Sieghardt and Karin Wriessnig for performing the manifold chemical analyses at the Inst. of Forest Ecology (BOKU-University). Thanks to Barbara Hinterstoisser, supervising the FT-NIR spectrometrical measurements of lignin at 
the Inst. of Wood Science and Technology (BOKU-University). Thanks to our "internal reviewer" Viktor Bruckman. We thank the forest owners (Lilienfeld Abbey, Kremsmünster Abbey, Austrian Federal Forests) for the possibility to perform this research on their properties. Finally, we thank two excellent reviewers for their critical comments for the improvement of this paper.

Open Access This article is distributed under the terms of the Creative Commons Attribution License which permits any use, distribution, and reproduction in any medium, provided the original author(s) and the source are credited.

\section{References}

Albers D, Migge S, Schaefer M, Scheu S (2004) Decomposition of beech leaves (Fagus sylvatica) and spruce needles (Picea abies) in pure and mixed stands of beech and spruce. Soil Biol Biochem 36:155-164

Berger TW, Neubauer C, Glatzel G (2002) Factors controlling soil carbon and nitrogen stores in pure stands of Norway spruce (Picea abies) and mixed species stands in Austria. For Ecol Manage 159:3-14

Berger TW, Köllensperger G, Wimmer R (2004a) Plant-soil feedback in spruce (Picea abies) and mixed spruce-beech (Fagus sylvatica) stands as indicated by dendrochemistry. Plant Soil 264:69-83

Berger TW, Sun B, Glatzel G (2004b) Soil seed banks of pure spruce (Picea abies) and adjacent mixed species stands. Plant Soil 264:53-67

Berger TW, Swoboda S, Prohaska T, Glatzel G (2006) The role of calcium uptake from deep soils for spruce (Picea abies) and beech (Fagus sylvatica). For Ecol Manage 229:234-246

Berger TW, Inselsbacher E, Mutsch F, Pfeffer M (2009a) Nutrient cycling and soil leaching in eighteen pure and mixed stands of beech (Fagus sylvatica) and spruce (Picea abies). For Ecol Manage 258:2578-2592

Berger TW, Untersteiner H, Toplitzer M, Neubauer C (2009b) Nutrient fluxes in pure and mixed stands of spruce (Picea abies) and beech (Fagus sylvatica). Plant Soil 322:317-342

Berger TW, Inselsbacher E, Zechmeister-Boltenstern S (2010) Carbon dioxide emissions of soils under pure and mixed stands of beech and spruce, affected by decomposing foliage litter mixtures. Soil Biol Biochem 42:986-997

Berger TW, Berger P (2012) Greater accumulation of litter in spruce (Picea abies) compared to beech (Fagus sylvatica) stands is not a consequence of the inherent recalcitrance of needles. Plant Soil 385:349-369

Carnol M, Bazgir M (2013) Nutrient return to the forest floor through litter and throughfall under 7 forest species after conversion from Norway spruce. For Ecol Manage 309:66-75

Dungait JAJ, Hopkins DW, Gregory AS, Whitmore AP (2012) Soil organic matter turnover is governed by accessibility not recalcitrance. Glob Chang Biol 18:1781-1796

Ellenberg H, Mayer R, Schauermann J (1986) Ökosystemforschung-Ergebnisse des Solling-Projekts 1966-1986. Ulmer, Stuttgart
Fyles JW, Fyles IH (1993) Interaction of Douglas-fir with red alder and salal foliage litter during decomposition. Can J For Res 23:358-361

Gartner TB, Cardon ZG (2004) Decomposition dynamics in mixed-species leaf litter. Oikos 104:230-246

Hector A, Beale AJ, Minns A, Otway SJ, Lawton JH (2000) Consequences of the reduction of plant diversity for litter decomposition: effects through litter quality and microenvironment. Oikos 90:357-371

Hoorens B, Coomes D, Aerts R (2010) Neighbour identity hardly affects litter-mixture effects on decomposition rates of New Zealand forest species. Oecologia 162:479-489

Jacob M, Viedenz K, Polle A, Thomas FM (2010) Leaf litter decomposition in temperate deciduous forest stands with a decreasing fraction of beech (Fagus sylvatica). Oecologia 164:1083-1094

Kazda M, Pichler M (1998) Priority assessment for conversion of Norway spruce forests through introduction of broadleaf species. For Ecol Manage 102:245-258

Klotzbücher T, Filley TR, Kaiser K, Kalbitz K (2011) A study of lignin degradation in leaf and needle litter using ${ }^{13} \mathrm{C}$-labelled tetramethylammonium hydroxide (TMAH) thermochemolysis: Comparison with $\mathrm{CuO}$ oxidation and van Soest methods. Org Geochem 42:1271-1278

Kristensen HL, Gundersen P, Callesen I, Reinds GJ (2004) Throughfall nitrogen deposition has different impacts on soil solution nitrate concentration in European coniferous and deciduous forests. Ecosystems 7:180-192

McTiernan KB, Ineson P, Coward PA (1997) Respiration and nutrient release from tree leaf litter mixtures. Oikos 78:527-538

Mucina L, Grabherr G, Ellmauer T (1993) Die Pflanzengesellschaften Österreichs. Teil 3: Wälder und Gebüsche. Gustav-Fischer, Jena, Stuttgart, New York

Prescott CE, Taylor BR, Parsons WFJ, Durall DM, Parkinson D (1993) Nutrient release from decomposing litter in Rocky Mountain coniferous forests: influence of nutrient availability. Can J For Res 23:1576-1586

Prescott CE, Zabek LM, Staley CL, Kabzems R (2000) Decomposition of broadleaf and needle litter in forests of British Columbia: influences of litter type, forest type, and litter mixtures. Can J For Res 30:1742-1750

Prescott CE, Blevins LL, Staley C (2004) Litter decomposition in British Columbia forests: controlling factors and influences of forest activities. JEM 5:44-57

Prescott CE (2010) Litter decomposition: what controls it and how can we alter it to sequester more carbon in forest soils? Biogeochemistry 101:133-149

Rehfuess KE (1990) Waldböden: Entwicklung, Eigenschaften und Nutzung. 2. Aufl. Parey, Hamburg

Sariyildiz T, Tüfek S, Kücük M (2005) Comparison of decomposition rates of beech (Fagus orientalis Lipsky) and spruce (Picea orientalis (L.) Link) litter in pure and mixed stands of both species in Artvin, Turkey. Turk J Agric For 29:429-438

Scheffer F, Schachtschabel P (1998) Lehrbuch der Bodenkunde. Ferdinand Enke Verlag, Stuttgart

Scheu S, Albers D, Alphei J, Buryn R, Klages U, Migge S, Platner C, Salamon J-A (2003) The soil fauna community in pure and mixed stands of beech and spruce of different age: trophic structure and structuring forces. Oikos 101:225-238

Schinner F, Öhlinger R, Kalender E, Margesin R (eds) (1996) Methods in soil biology. Springer, Berlin Heidelberg, New York 
Schlesinger WH (1997) Biogeochemistry: an analysis of global change, 2nd edn. Academic, San Diego

Schmid I, Kazda M (2001) Vertical distribution and radial growth of coarse roots in pure and mixed stands of Fagus sylvatica and Picea abies. Can J For Res 31:539-548

Schmid I, Kazda M (2002) Root distribution of Norway spruce in monospecific and mixed stands on different soils. For Ecol Manage 159:37-47

Schwanninger M, Hinterstoisser B (2002) Klason lignin: Modifications to improve the precision of the standardized determination. Holzforschung 56:161-166

Schwanninger M, Hinterstoisser B, Gierlinger N (2009) Selected applications of NIR in wood science. In: Tsuchikawa S (eds) Proceedings of the 25th NIR Forum, Japan Council of NIR Spectroscopy (JCNIRS), Nagoya University, pp 89-99
Spiecker H, Hansen J, Klimo E, Skovsgaard JP, Sterba H, von Teuffel K (eds) (2004) Norway spruce conversion - options and consequences. Research report 18, European Forest Institute, Brill, Leiden, Boston

Vesterdal L (1999) Influence of soil type on mass loss and nutrient release from decomposing foliage litter of beech and Norway spruce. Can J For Res 29:95-105

Vivanco L, Austin AT (2008) Tree species identity alters forest litter decomposition through long-term plant and soil interactions in Patagonia, Argentina. J Ecol 96: 727-736

Wardle DA, Bonner KI, Nicholson KS (1997) Biodiversity and plant litter: experimental evidence which does not support the view that enhanced species richness improves ecosystem function. Oikos 79:247-258 